\title{
FIRE RESISTANCE GLAZED CONSTRUCTIONS CLASSIFICATION Changes in the field of application
}

\author{
Jacek Kinowski, Bartłomiej Sędłak, Paweł Sulik, Daniel Izydorczyk \\ Building Research Institute, Fire Research Department, Warsaw, Poland
}

\begin{abstract}
The most common fire resistance glazed constructions are arguably doors and non - loadbearing walls (partitions, curtain walls, external walls). In 2014 we welcomed revisions of fire resistance testing standards for doors (EN 1634-1) and curtain walls (EN-1364-3), while revision of EN 13641 standard for non - loadbearing walls is planned to be implemented by the end of the year 2015 . Taking into account the existence of several EXAP's for all these kind of constructions, selection of test specimen(s) with best possible configuration is getting more significant nowadays. But equally important question appears - how to treat previously performed fire resistance tests?

This paper discusses some interpretation concerns regarding fire resistance classifications of aluminium glazed, non - loadbearing constructions in light of rapidly changing regulations. The paper also points out same examples of testing evidence with regard to outlined concerns.
\end{abstract}

Keywords: glazed constructions, fire resistance, integrity, insulation, classification report

\section{INTRODUCTION}

One of the essential elements of the most common fire resistant constructions is the glazing. Each system owner would love to have the right to declare certain fire resistance class of his product with as wide range of different glass panes as possible. How to minimise number of tests requires careful consideration but without doubt some concerns will arise (Kinowski et al., 2014; Kinowski 2015; Sędłak et al., 2012; Sulik et al., 2015). In this paper a short, to -date list of existing rules, and summarise of given remarks is presented. The other discussed topic concerns treatment of previously performed (under old, already revised test standard) tests on the example of additional thermocouples for maximum temperature rise.

\section{RULES OF ASSESMENT}

Recently issued Product Standard for Pedestrian doorsets, industrial, commercial, garage doors and openable windows (PN-16034) came up with good definition of how should we treat fire resistance tests performed under the already revised standard: "Assessment previously performed in accordance with the provisions of this standard, may be taken into account provided that they were made to the same or a more rigorous test method (...)". Rule seems to be reasonable, but may turns out to be troublesome if you treat it literally.

\subsection{Additional Thermocouples}

As an example, we took fire resistance tests of curtain walls (Sędłak et al., 2013) performed under the 1364-3:2014 standard, that requires additional thermocouples of maximum temperature raise placed (inter alia) at mid-width of the pane with the largest area, $20 \mathrm{~mm}$ from the horizontal framing and in the top corners of the pane with the largest area, and in the top corners of the highest placed pane $20 \mathrm{~mm}$ from the horizontal and vertical framing members. Photos from three different fire resistance tests of curtain walls in full configuration are presented in figures 1, 4, 6 with diagrams with comparison of temperature rises on "old" and "new" thermocouples in figures 3, 5, 7. 


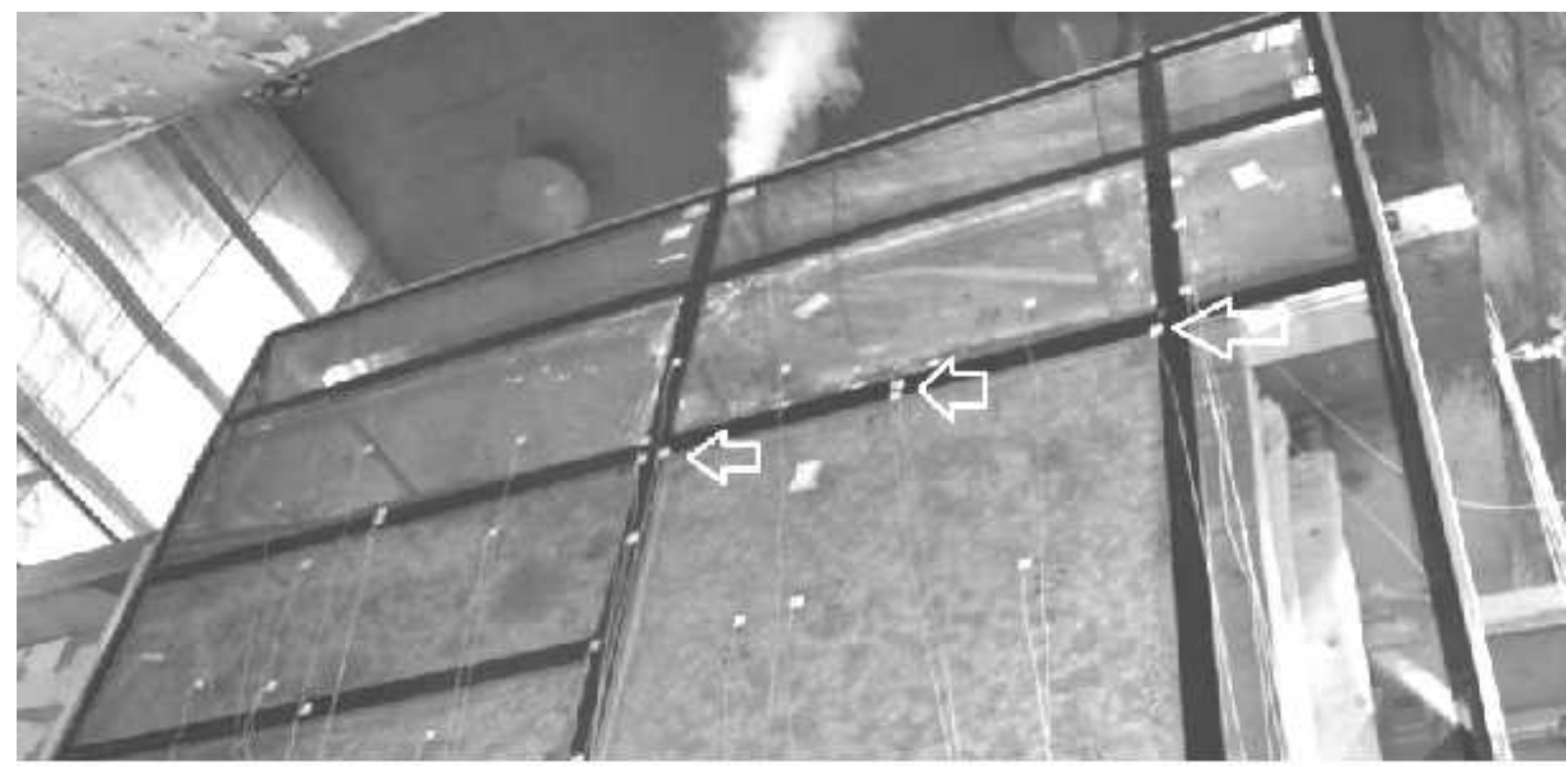

Fig. 1 Additional thermocouples placement in fire resistance test of curtain wall, test 1

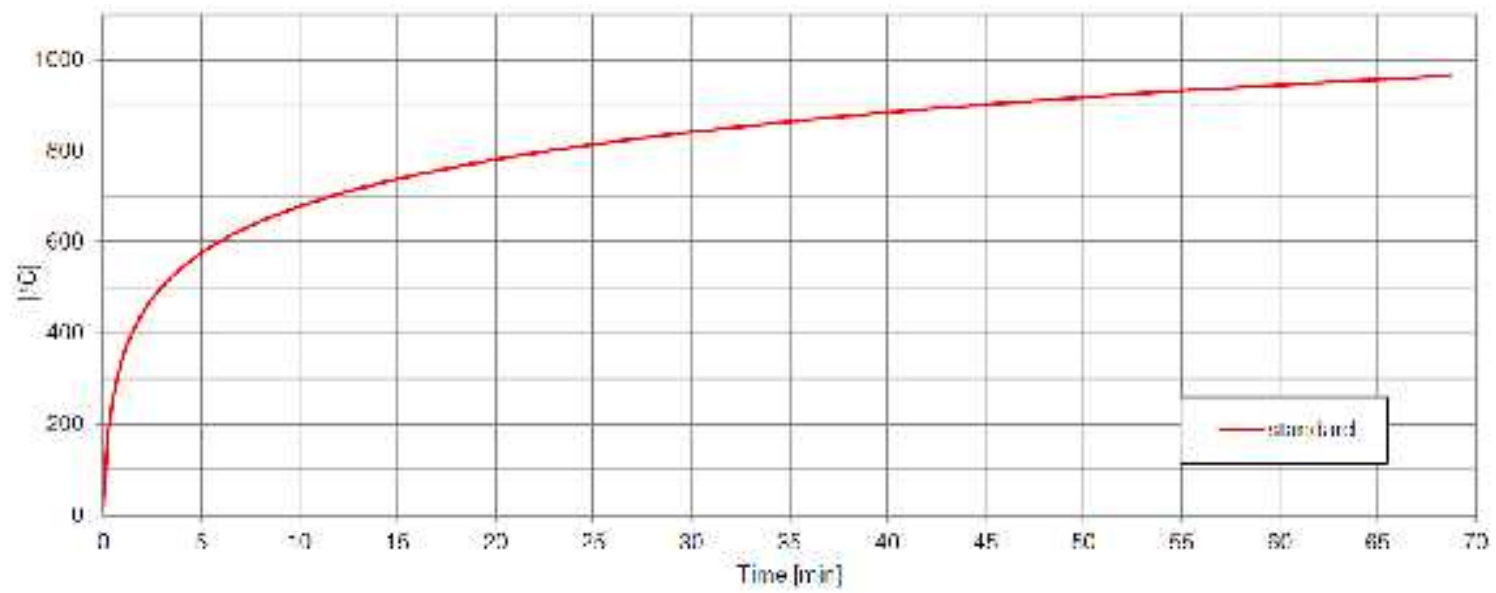

Fig. 2 Temperature/ time curve of furnace heating (tests $1-3$ )

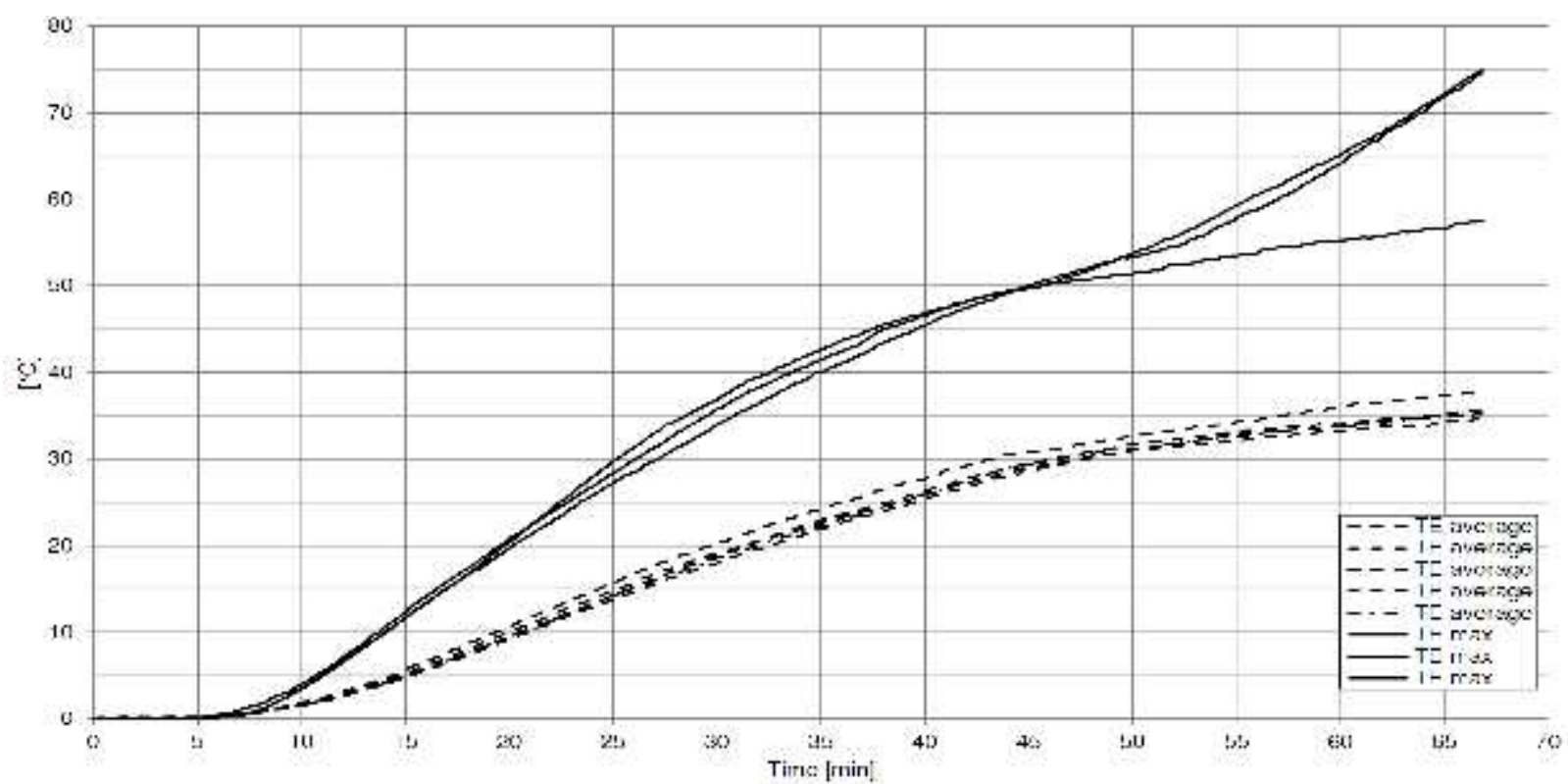

Fig. 3 Comparison of temperature rises on "old" thermocouples for average temperature rise measurements (TE average) and "new" thermocouples for maximum temperature rise measurements, test 1 


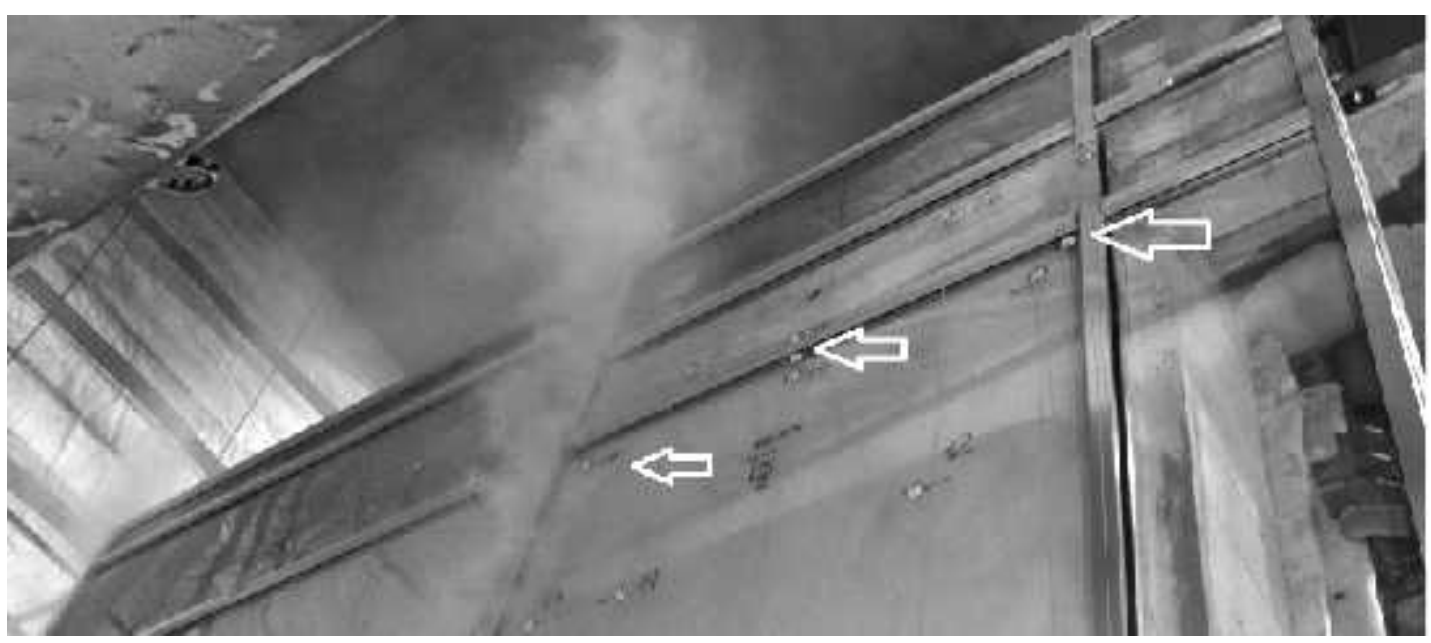

Fig. 4 Additional thermocouples placement in fire resistance test of curtain wall, test 2

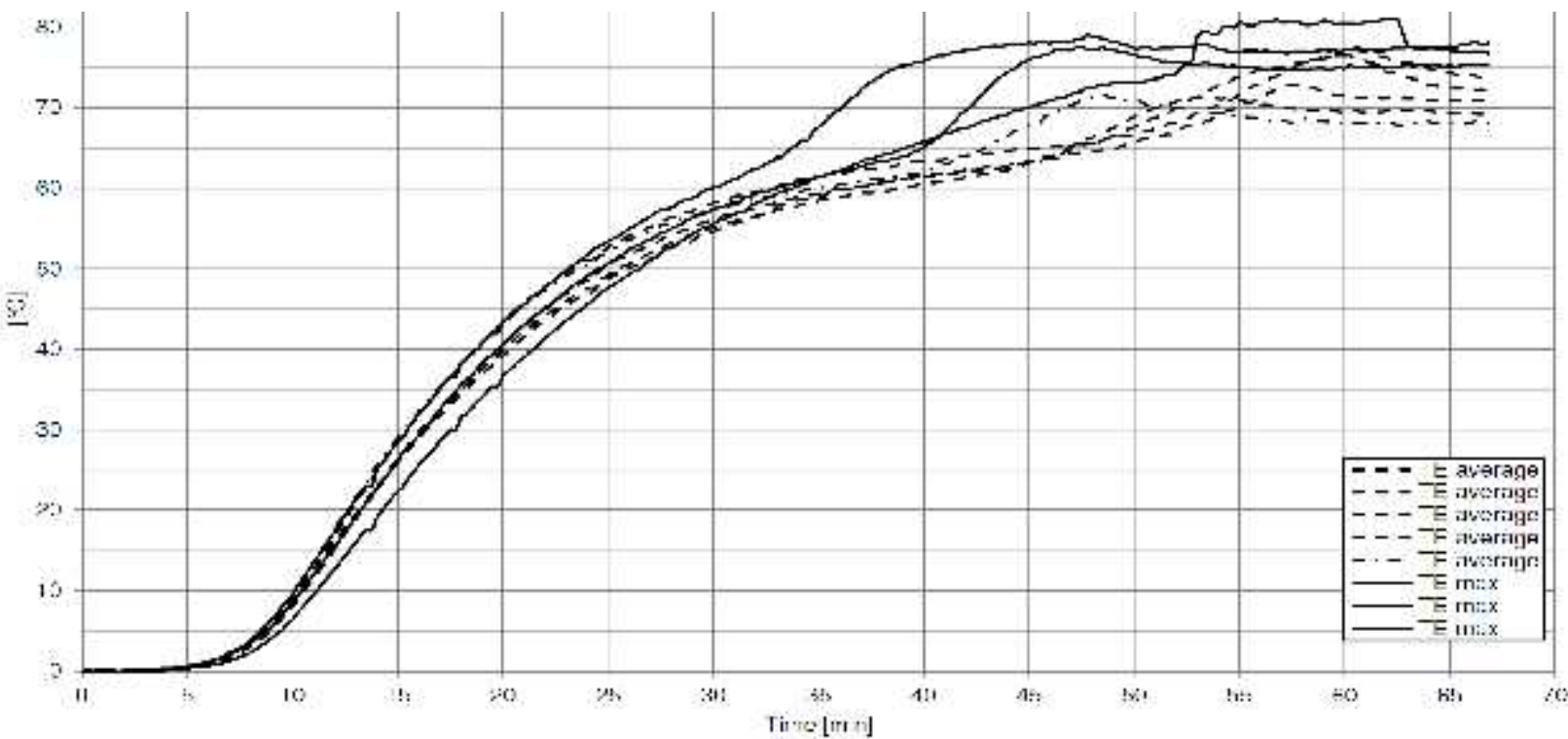

Fig. 5 Comparison of temperature rises on "old" thermocouples for average temperature rise measurements (TE average) and "new" thermocouples for maximum temperature rise measurements, test 2

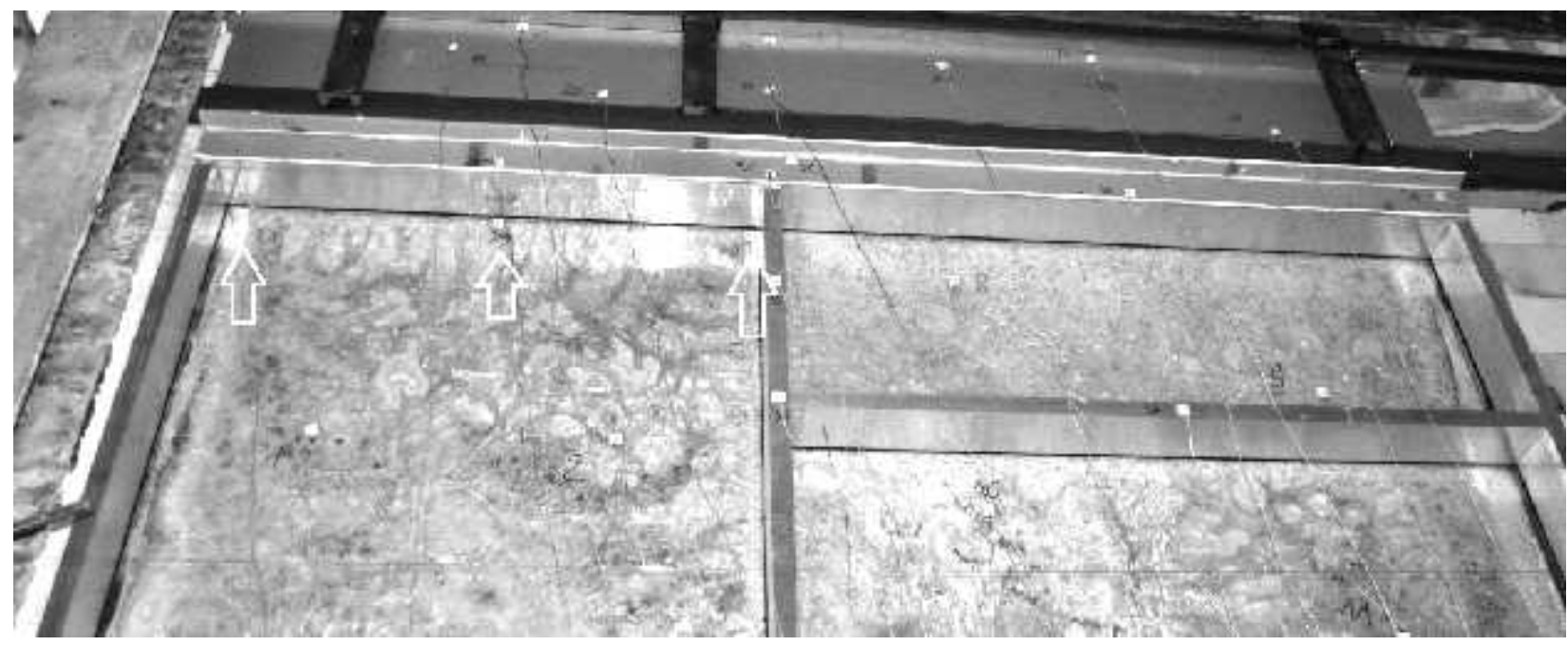

Fig. 6 Additional thermocouples placement in fire resistance test of curtain wall, test 3 


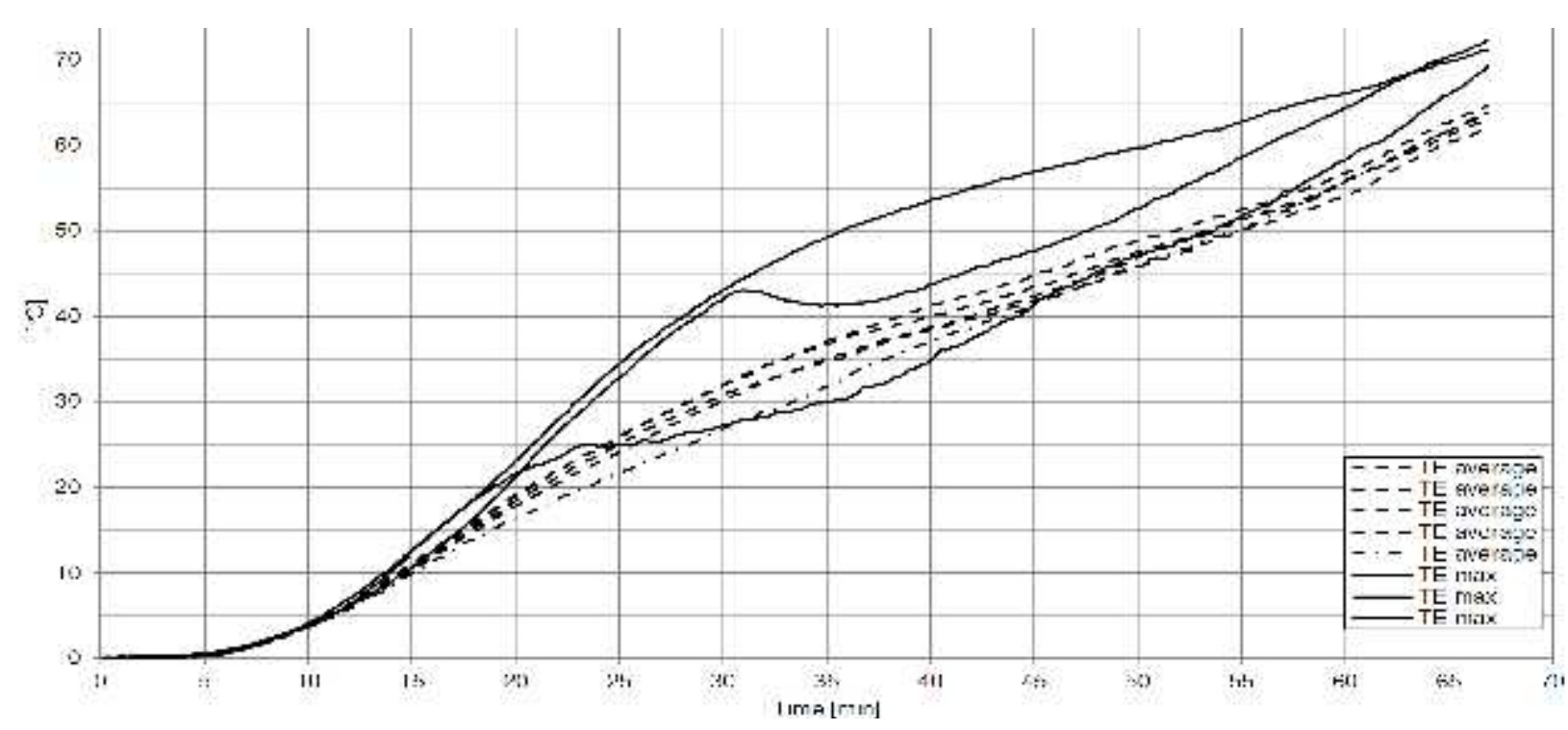

Fig. 7 Comparison of temperature rises on "old" thermocouples for average temperature rise measurements (TE average) and "new" thermocouples for maximum temperature rise measurements, test 3

It can be assumed from the figures above, that generally temperature rises on thermocouples placed according to new version of Standard are greater than temperature rises on thermocouples placed according to previous version of Standard. Still though, temperature rises are not critical for achieving integrity performance criteria. In this context it seems that taking into account fire resistance tests without temperature rises measurements in "new" places is reasonable, but some can argue it's not exactly according the rule, because based on testing experience, we can say that the old test method were clearly less "rigorous".

\subsection{Exchange of fire resistance glass for walls and doorsets}

Currently we have really big differentiation with approach of how to exchange the fire resistance glass in different types of construction. Rules for "doors" are in some sense quite similar to rules for "walls", while with curtain walls we have completely separate guidelines. For doors, partitions and external walls the key is the concept of the same glass family product and minimum thickness of the glass pane: "the exchange of the tested glass for another fire resistant glass is allowed, provided that it can be demonstrated that both glasses are within the same glass product group (same manufacturer) and have at least the same or increased nominal thickness" - says the definition from EN 15254-4. It has to be mentioned though, that in other part of EXAP for non-loadbearing glazed wall there is one more definition that puts in doubt the previous rule: "the replacement glass must have evidence that it achieves at least the same fire resistance classification as the reference glass". In this context some can argue that in order to exchange tested glass pane of one glass product group with another of the same (sic!) glass product group, additional data of fire resistance test of the new glass pane is still needed. And because of the fact, that glass panes on their own do not have a classification, some can argue that fire resistance test of the considered wall glazed with new glass panes is needed. And that is only for exchanging one glass with glass of the same glass product group - no rules for exchanging between different glass product groups is given.

In opposition to this, PN-EN 15269-5:EXAP for doors provides rule for exchanging glass pane of one family glass product with another, based on the following condition: "additional test can be single or double leaf doorset (open outwards)".

\subsection{Exchange of fire resistance glass for curtain walls}

Standards for curtain walls (EN 1364-3:2014 and EN 1364-4:2014) provides much better specified definition of glass pane types presented below. 


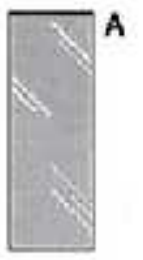

monolithic pane, a laminated pane of gel type glass pane

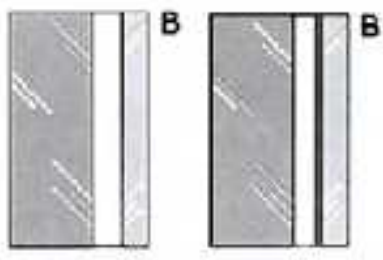

IGU (insulated glass unit) consisting of the part that gives the fire resistance and a single pane for UV' acoustic/ safety performance, with or wtihout additional coatings on either side of the counter pane)

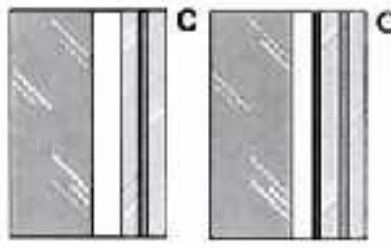

C ISil (insilated glass unit) consisting of the part thal givex lhe fite resislance arret a

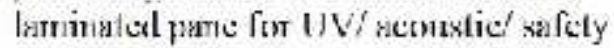
performanes (countcr pate), with or wilhoul additional coaliniss on cilher side of (hic counter pante)

Fig. 8 Types of glass panes according to EN - 1364-3

Rules for possible exchanging of fire resistance glass panes are given precisely based on type of the glass panes and heating site of the glass pane. Given the the specificity of the asymmetric glass panes units behaviour in fire resistance tests (Sędłak et al., 2014), this looks like the right approach. On figures below several fire resistance tests failures caused directly by imperfections of glass pane units are presented.

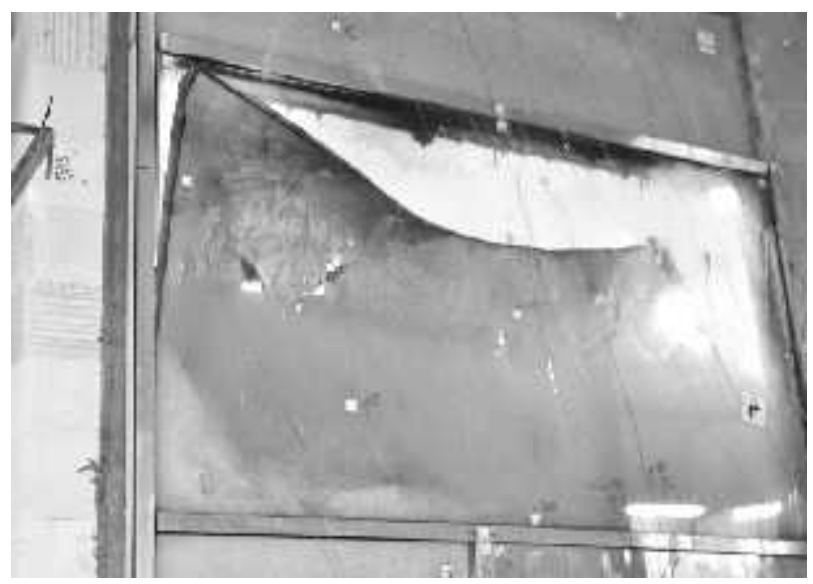

Fig. 8 IGU glass of EI90 type failure
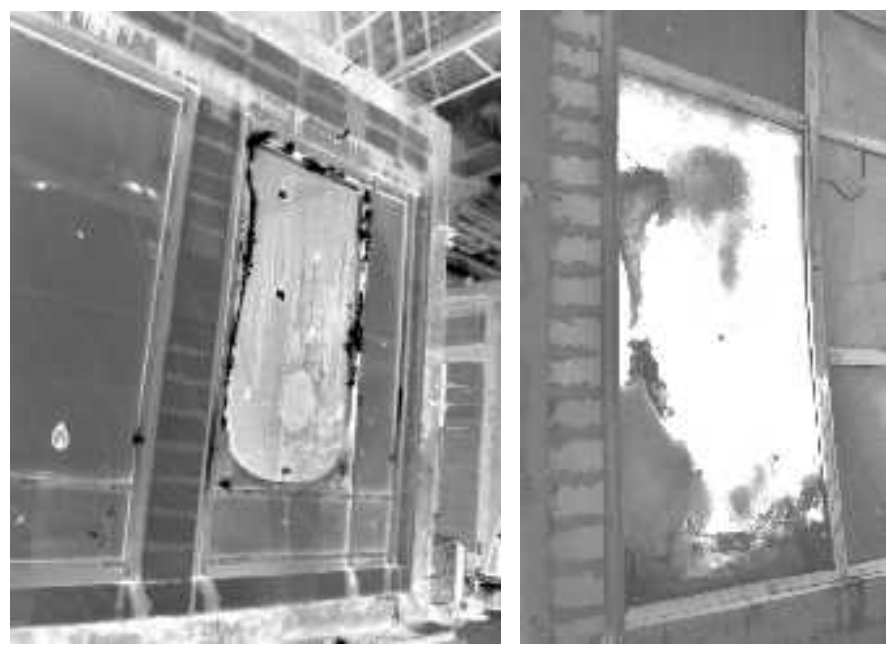

Fig. 9, 10. Photos form two different tests (Photo on the left is in negative) 


\section{CONCLUSIONS}

In this paper some of typical interpretation problems that arise during the preparation process of the fire resistant glazed construction classification were presented. Some of the concerns are likely to be explained through appropriate EXAP's revisions. Nowadays harmonized approach is particularly important for products intended for CE marking such as doors and curtain walls, although it would be surprising if the rules for walls remained different.

\section{NORMATIVE REFERENCES}

EN 1634-1:2014 Fire resistance and smoke control tests for door and shutter assemblies, openable windows and elements of building hardware -Part 1: Fire resistance test for door and shutter assemblies and openable windows

EN 1364-3:2014 Fire resistance tests for non-loadbearing elements. Curtain walling. Full configuration (complete assembly)

EN 1364-1:1999 Fire resistance tests for non-loadbearing elements - Part 1: Walls;

FprEN 1364-1 October 2014 Working group document on revision of test standard.

EN 13501-2:2007+A1:2009 Fire classification of construction products and building elements Part 2: Classification using data from fire resistance tests, excluding ventilation services;

PN-EN 15269-5:2014 Extended application of test results for fire resistance and/or smoke control for door, shutter and openable window assemblies, including their elements of building hardware Part 5: Fire resistance of hinged and pivoted metal framed glazed doorsets and openable windows EN 15254-4:2008+A1:2011 - Extended application of results from fire resistance tests - Nonloadbearing walls - Part 4: Glazed constructions;

\section{REFERENCES}

Kinowski J., 2015. Bezpieczeństwo po arowe przeszklonych ścian ostonowych (kurtynowych). Świat Szkła, 20(5), p. 8-14.

Kinowski J., Sędłak B., Sulik P., 2015. Izolacyjność ogniowa aluminiowo - szklanych ścian osłonowych w zale ności od sposobu wypetnienia profili szkieletu konstrukcyjnego. Izolacje, 20(2), p. 48-53.

Kinowski J., Sulik P., 2014. Bezpieczeństwo u ytkowania elewacji. Materiaty Budowlane, 9, p. 38-39.

Sędłak B., 2012. Badania odporności ogniowej przeszklonych ścian osłonowych - Częś́́ 1. Świat Szkła, $17(9)$, p. $52-54$.

Sędłak B., 2012. Badania odporności ogniowej przeszklonych ścian osłonowych - Czesść 2. Świat Szkła, $17(10)$, p. 53-58,60.

Sędłak B., 2013. Systemy przegród aluminiowo szklanych o określonej klasie odporności ogniowej. Świat Szkta, 18(10), p. 30-33,41.

Sędłak B., 2014. Badania odporności ogniowej przeszklonych ścian ostonowych wg nowego wydania normy $P N-E N$ 1364-3. Świat Szkta, 19(7-8), p. 49-53.

Sędłak B., 2014. Odporność ogniowa ścian ostonowych z du ymi przeszkleniami - Część 1. Świat Szkła, 19(3), p. 16-19,25.

Sędłak B., 2014. Odporność ogniowa ścian osłonowych z du ymi przeszkleniami - Część 2. Świat Szkła, 19(5), p. 28-31.

Sędłak B., Kinowski J., 2013. Badania odporności ogniowej ścian osłonowych - przyrosty temperatury na szybach. Świat Szkta, 18(11), p. 20-25.

Sędłak B., Kinowski J., Borowy A., 2013. Fire resistance tests of large glazed aluminium curtain wall test specimens-results comparison. MATEC Web of Conferences, 9, p. 02009, EDP Sciences, DOI: 10.1051/matecconf/20130902009.

Sulik P., Sędłak B., Kinowski J., 2014. Bezpieczeństwo po arowe ścian zewnętrznych - Częśś 1 - Elewacje szklane: wymagania, badania, przyktady. Ochrona przeciwpo arowa, 4(50), p. 10-16.

Sulik P., Sędłak B., Kinowski J., 2015. Bezpieczeństwo po arowe ścian zewnętrznych - Część 2 Mocowanie okładzin elewacyjnych. Ochrona przeciwpo arowa, 1(51), 9-12. 